\title{
Clay Minerals Variations in Quaternary Sediments of Basrah City-Iraq
}

\author{
Mohanad Hamid Al-Jaberi ${ }^{1}$ \\ ${ }^{1}$ Basrah University- Science college- Geology department, Iraq \\ Correspondence: Mohanad Hamid Al-Jaberi, Basrah University- Science college- Geology department, Iraq. \\ E-mail: jaberi76@yahoo.com
}

Received: January 27, 2017

Accepted: February 1, 2017

Online Published: April 8, 2017

doi:10.5539/esr.v6n2p41

URL: https://doi.org/10.5539/esr.v6n2p41

\begin{abstract}
Mineralogical and chemical analysis of two well cutting in quaternary sediments at Basrah city. This study have been focused on the quaternary clay minerals variations which give a clear indication to marine transgression and or / regression in Hammar formation. Kaolinite, Illite, Palygoreskite, Illite-Palygorestike mixed layer, Chlorite, Montmorillonite, Vermiculte, and mixed layers of Illite- Smectite are the most quantitatively important phyllosilicates in soil studies in both boreholes. The mineralogical composition of cutting sediments shows significant variability in the different size fractions and depth distribution. Chlorite and kaolinite minerals were increase in the fine grain size especially in the clayey silt, whereas montmoriollinite and vermiculite minerals were increase in coarse grains especially in silty sand texture. Kaolinite decrease in abundance with depth, which give indicative of a transition from non-marine in quaternary recent sediment ( fresh or brackish water silt) to marine facies in quaternary Hammar formation ( marine shelly silt) during last transgression of quaternary. Palygoreskite mineral percentages increasing at depths 27 and 28 meter, after decreased at 30, 32, 35, and $40 \mathrm{~m}$ respectively, which give data indication that early quaternary marine transgression happened in $32 \mathrm{~m}$, and center of quaternary marine transgression detected in 27 and 28 meters, while late marine transgression detected in 17 $\mathrm{m}$, and all of these represent by Hammar formation. Soil ageing also caused to downward increase of montmorillonite suggest to climate became more arid during the early quaternary. Variations ratio of montmorillonite versus kaolinite can be indicated to climatic fluctuation. Illite-Semectite featured indicates changes in both sediment source and paleoclimate. Illite transformation for Illite-Palygoreskite mixed layers with ageing. Vermiculite has strong susceptibility to increase with age. $\mathrm{SiO}_{2}, \mathrm{Al}_{2} \mathrm{O}_{3}, \mathrm{CaO}, \mathrm{MgO}, \mathrm{K}_{2} \mathrm{O}$, and $\mathrm{Fe}_{2} \mathrm{O}_{3}$ were the major oxides that identified in present study and used as indicated of clay minerals in studied sediments.
\end{abstract}

Keywords: quaternary, hammar, paleoenvironment, basrah city, recent sediments, minerals variations

\section{Introduction}

Clay mineral analysis has been widely used to characterize soil parent material and to relate it to the bedrock (Bronger et al., 1994; Iacoviello and Martini, 2012), as well as to associate mineralogical transformation with changes in climate and weathering intensity ( Bini and Mondini, 1992). Distributions of clay minerals can be used for the reconstruction of paleoclimates and paleoenvironments, especially if it coupled with geological, geomorphological, and soil surveys studies (Vanderaveroet et al., 1999, Costantini and Damiani, 2004). Montmorillonite, illite, chlorite, and kaolinite are the major four proxies of clay minerals to test paleoenvironmental hypotheses. Larsen and Chilingar (1967) and Keller (1970) point to higher amount of alumina content in kaolinite minerals between (20-40\%) in acidic climate, and both of Tucker (1985) and Velde (1992) stated that kaolinite is product during chemical weathering in higher temperature and moisture climate. Montmorillonite is indicate to alkaline environment (Millot, 1970; Weaver and Pollard, 1975). Selley (1976) stated that montmorillonite minerals have more than $20 \%$ of water, calcium and magnesium. Chlorite and Illite tend to be linked to a cold and/or temperature climate regime, where physical weathering predominates (Millote,1970; Carroll, 1970; Velde,1992). Chlorite minerals have a higher percent of iron ions while illite have a higher amount of potassium ions as mentioned previously by Correns (1973) and Selley (1994). The quaternary deposits in the southern Mesopotamian basin consist of complicated interbedded sequences of sand, silt and clay (sometimes rich in organic materials) (Al-Jumaily, 1994; Al-Jaberi, 2010). These sequences mostly represent the fluviatile, lacustrine, and deltaic sediments (Budy, 1980). The present study aims to evaluate the temporal distribution of clay minerals of quaternary deposits in two boreholes in center of Basrah city (Figure 1), additionally, to discuss the change of sediment sources through time and to reveal possible relationship with 
climate and environmental changes.

\section{Study Area}

Two boreholes were choose in Basrah city center-Southern Iraq, the first one were located at $30^{\circ} 32^{\prime} 18.36^{\prime \prime} \mathrm{N}$ and

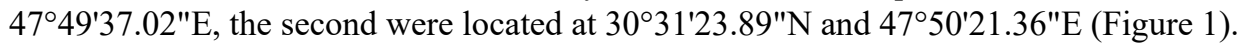

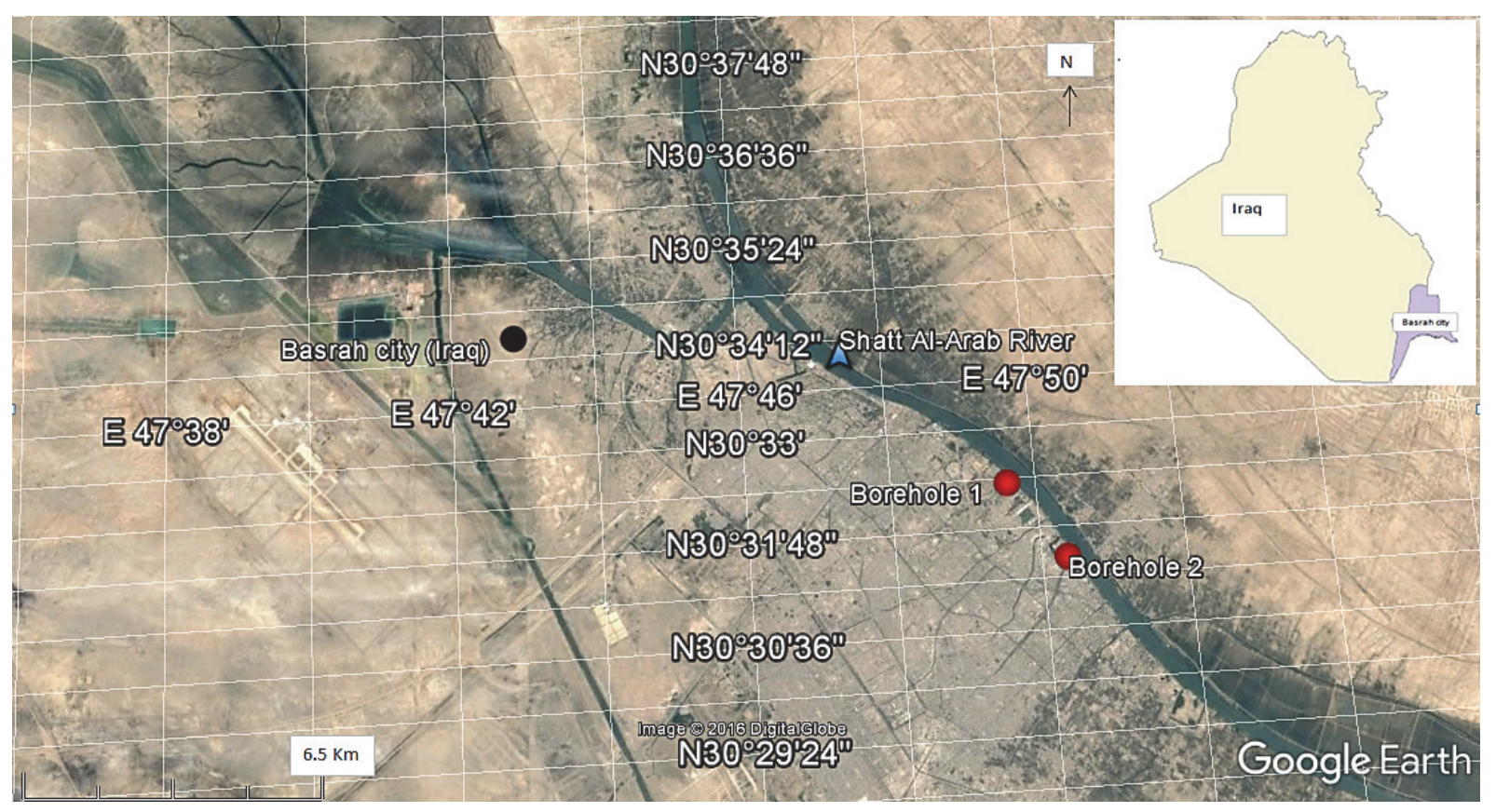

Figure 1. Map of study area

\section{Materials and Methods}

Sediments boreholes $40 \mathrm{~m}$ depth, was drilled by used rotary rig in two position of Basrah city center in 2016 (Figure 1). On- site sediment description was made during the coring. Sediment lithology, bedding, fauna, fossils, plant fragment and all of sediment details logging was carried out in the laboratory when splitting the cutting samples. Clay minerals assemblages for each boreholes were conducted for depths $3,9.13,17,23,26,27,28,30$, 32,35 , and 40 meters basis of lithologic changes in the section. All samples was carried out by successive washing with distilled water after adding $\mathrm{H}_{2} \mathrm{O}_{2}$ and $10 \% \mathrm{HCl}$. particles less than $0.02 \mathrm{~mm}$ were separated by adding $15 \mathrm{ml}$ of Na- Hexameta Phosphate according to Folk (1974). X-Ray diffraction (XRD) measurement were performed under 3 conditions separately, air-dried, ethylene glycol, and heated at $550^{\circ} \mathrm{c}$ for 2 hours. X-ray diffraction patterns were obtained by means of D-5000 X-ray diffractometer, using $\mathrm{CuK} \alpha$ source in wave- length, $\mathrm{v}=1.54056 \AA$ at $40 \mathrm{kV}$ and $30 \mathrm{~mA}$ between $5-40^{\circ}$ and $5-62 \theta$ for non-clay minerals and $2-20^{\circ}$ for oriented clay minerals in step of 0.04 and step time at an interval of 1.5 per second using a rotating sample holder. Geochemical analysis (Major oxides) calculated by inductively coupled plasma Atomic emission spectrometry (ICP-AES), and inductively coupled plasma Mass spectrometry (ICP-MS) in the ALS Laboratory group in Spain and Sweden.

\section{Grain Size Analysis}

Variation content of sand, silt and clay in two boreholes sediments were stated in tables (1 and 2) and figures (3 and 4). Sediments texture classified according to Picard (1971). Table (1) and figure (2) showed grain size analysis and texture for cutting sediments in borehole (1). Silt and clay fractions were dominant at depth of 0.5 to 23.5 meters with clayeysilt texture, while sand content started increment from $63 \%$ at depth 26 meter to $70 \%$ at 40 meter with texture siltysand as shown in table (1) and figure (2). Results of grain size analysis of cutting sediments in borehole (2) were shown in table (2) and figure (3). Silt and clay fractions were superior in this borehole from 1.5 meter depth to 21.5 meter with clayeysilt texture, while sand content started increased from $55 \%$ at depth of 24 meter to $73 \%$ at 40 meter with siltysand texture. 
Table 1. Grain size and texture of cutting sediments in borehole (1)

\begin{tabular}{lcccl}
\hline $\begin{array}{l}\text { Depth (m) } \\
\text { From - to }\end{array}$ & Clay \% & Silt\% & Sand\% & Texture \\
\hline $0.5-1 \mathrm{~m}$ & 23 & 77 & 0 & Clayeysilt \\
$3-3.5 \mathrm{~m}$ & 28 & 72 & 0 & Clayeysilt \\
$6-6.5 \mathrm{~m}$ & 26 & 71 & 3 & Clayeysilt \\
$8-8.5 \mathrm{~m}$ & 40 & 56 & 4 & Clayeysilt \\
$11-11.5 \mathrm{~m}$ & 16 & 80 & 4 & Clayeysilt \\
$14-14.5 \mathrm{~m}$ & 17 & 81 & 2 & Clayeysilt \\
$17-17.5 \mathrm{~m}$ & 21 & 74 & 5 & Clayeysilt \\
$20-20.5 \mathrm{~m}$ & 18 & 75 & 7 & Clayeysilt \\
$23-23.5 \mathrm{~m}$ & 17 & 80 & 3 & Clayeysilt \\
$26-26.5 \mathrm{~m}$ & 10 & 27 & 63 & Siltysand \\
$29-29.5 \mathrm{~m}$ & 9 & 29 & 62 & Siltysand \\
$31-31.5 \mathrm{~m}$ & 9 & 31 & 60 & Siltysand \\
$33-33.5 \mathrm{~m}$ & 8 & 30 & 62 & Siltysand \\
$35-35.5 \mathrm{~m}$ & 8 & 25 & 67 & Siltysand \\
$39-40 \mathrm{~m}$ & 7 & 23 & 70 & Siltysand \\
\hline
\end{tabular}

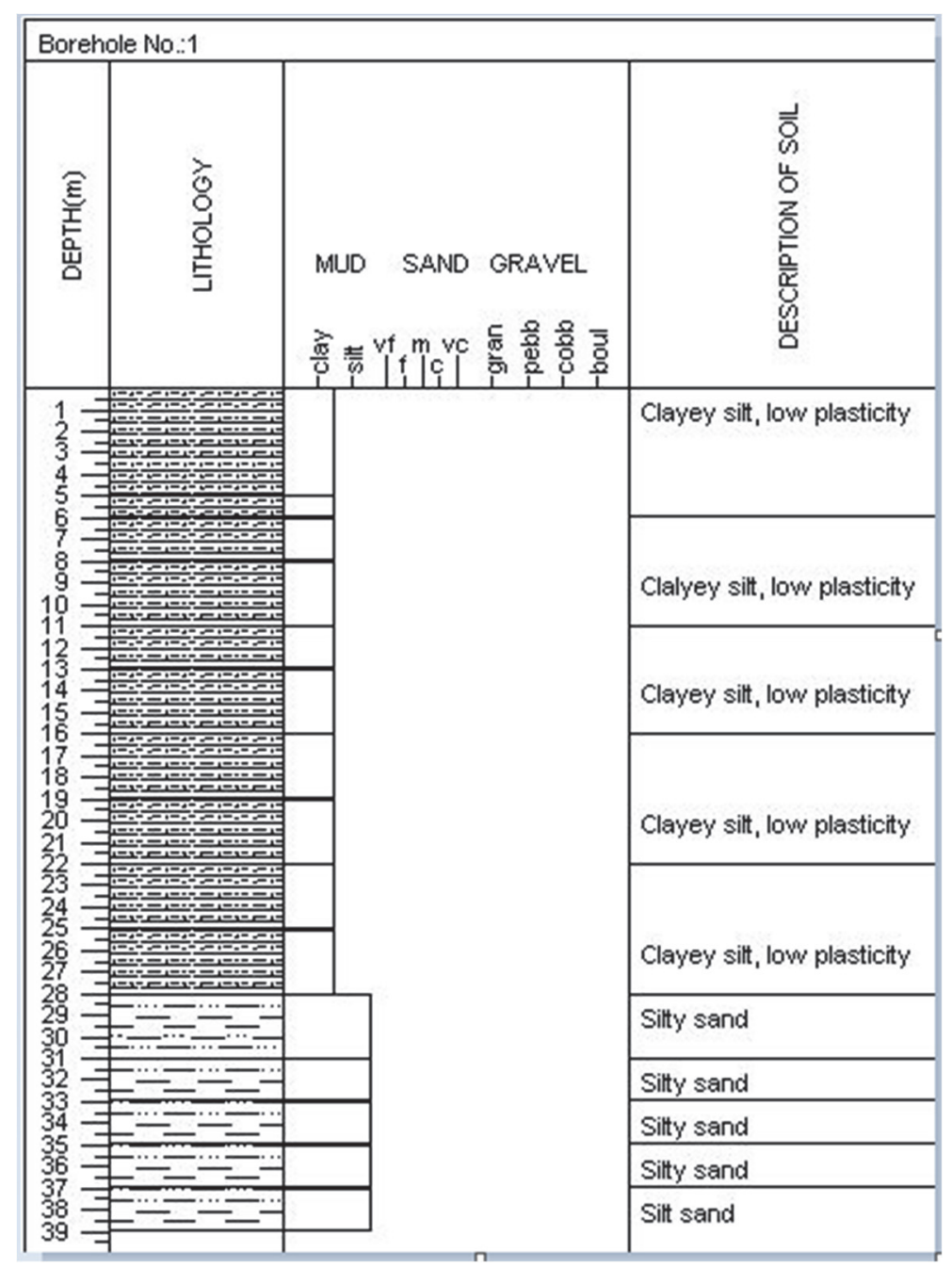

Figure 2. Sediment log of cutting sediments in borehole (1) 
Table 2. Grain size analysis and texture of cutting sediments in borehole (2)

\begin{tabular}{lcccl}
\hline $\begin{array}{l}\text { Depth (m) } \\
\text { From - to }\end{array}$ & Clay \% & Silt\% & Sand\% & Texture \\
\hline $1-1.5 \mathrm{~m}$ & 33 & 67 & 0 & Clayeysilt \\
$4-4.5 \mathrm{~m}$ & 21 & 76 & 3 & Clayeysilt \\
$7-7.5 \mathrm{~m}$ & 19 & 78 & 3 & Clayeysilt \\
$10-10.5 \mathrm{~m}$ & 20 & 80 & 0 & Clayeysilt \\
$13-13.5 \mathrm{~m}$ & 18 & 80 & 2 & Clayeysilt \\
$16-16.5 \mathrm{~m}$ & 19 & 79 & 2 & Clayeysilt \\
$19-19.5 \mathrm{~m}$ & 23 & 67 & 10 & Clayeysilt \\
$21-21.5 \mathrm{~m}$ & 36 & 55 & 9 & Clayeysilt \\
$24-24.5 \mathrm{~m}$ & 10 & 35 & 55 & Siltysand \\
$27-27.5 \mathrm{~m}$ & 10 & 29 & 61 & Siltysand \\
$30-30.5 \mathrm{~m}$ & 9 & 35 & 56 & Siltysand \\
$33-33.5 \mathrm{~m}$ & 9 & 31 & 60 & Siltysand \\
$35-35.5 \mathrm{~m}$ & 8 & 20 & 72 & Siltysand \\
$39-40 \mathrm{~m}$ & 7 & 20 & 73 & Siltysand \\
\hline & & & & \\
\hline
\end{tabular}

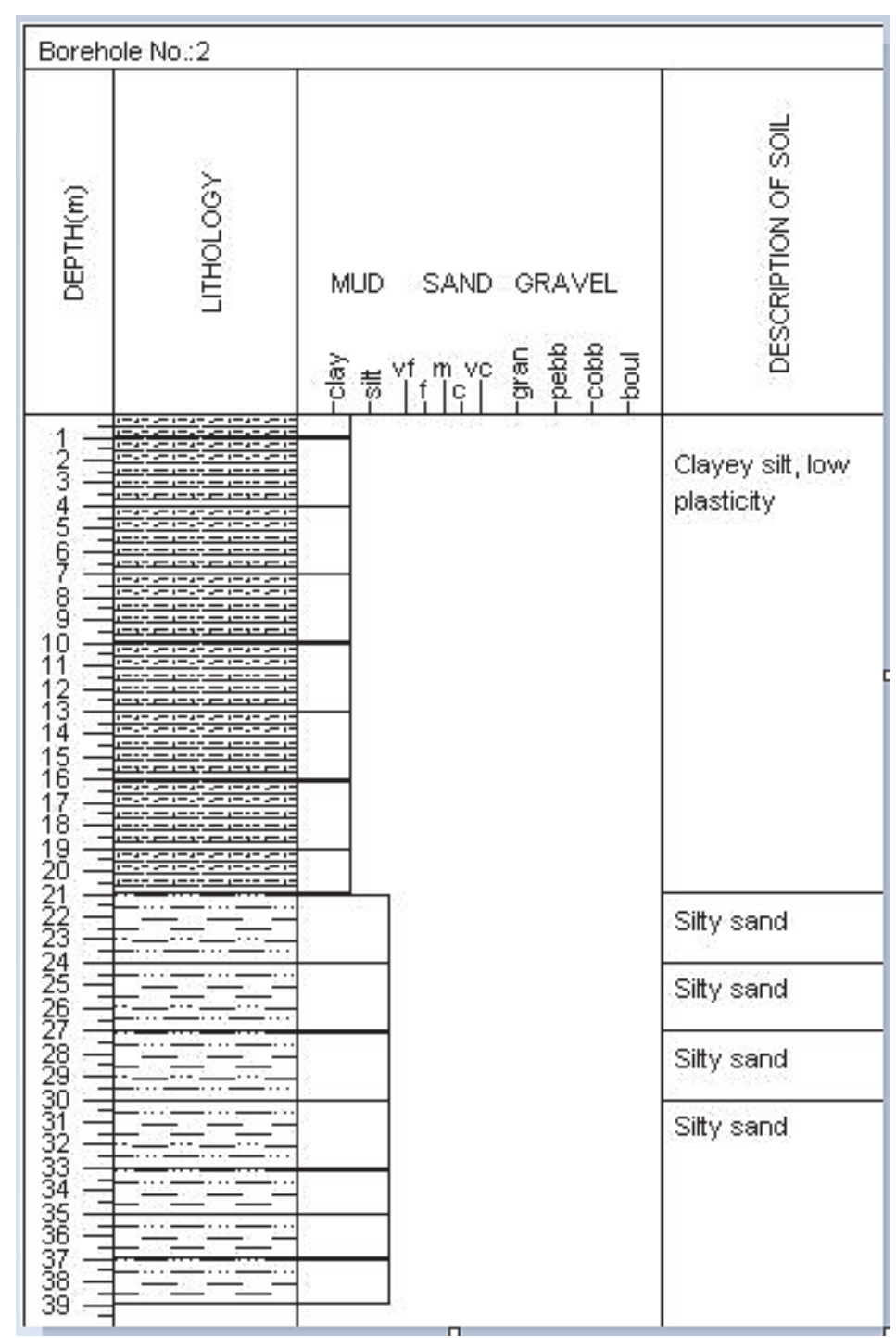

Figure 3. Sediment log of cutting sediments in borehole (2) 


\section{Clay Minerals Distribution}

Nine principal clay minerals were identified in borehole sediments : Palygoreskite, Chlorite- Montmorillonite mixed layer, Illite, Chlorite, montmorillonite, Kaolinite, Vermiculte, , mixed layer Illite-Smectite and Illite-Palygorestike respectively. These minerals were identified by methods described by Carrol (1970), Brindley and Brown (1980), and Reynolds (1980) (Figures 6 to 17).

Clay minerals content at different depths clarified in tables (3 and 4) and figures (4 and 5). Palygoreskite dominates ranging from $10-55 \%$ with average $21 \%$ in borehole (1) and between $11-57 \%$ with average of $21 \%$ in borehole (2). Illite is secondary from $4-45 \%$ with average $20 \%$ in borehole (1), and ranging from $5-40 \%$ with average $19 \%$ in borehole (2). Mixed layers of Chlorite- Montmorillonite is third ranging from $13-54 \%$ with average of $19 \%$ in borehole (1), while average of these layers in borehole (2) ranging between $3-51 \%$ with average $18 \%$. Kaolinite is decreasing trend downward in the cutting, ranging from $8-20 \%$ with average $15 \%$ in borehole (1) and ranging between $7-25 \%$ with average $15 \%$ in borehole (2). Montmorillonite is increasing trend with depth , ranging from $7-30 \%$ with average of $10 \%$ in borehole (1), whereas ranging from $6-30 \%$ in borehole (2) with average $11 \%$. Whereas Chlorite ranges from $8-42 \%$ with average $6 \%$, while ranging in borehole (2) between 3-40\% with average of 6\%. Mixed layer of Illite- Palygoreskite present just in depth of 26 meter with $31 \%$ in borehole (1) and 38\% in borehole (2). Vermiculite existed in deep sediments ranging from $19-27 \%$ with average of $7 \%$ in borehole (1), and ranging from $18-27 \%$ in borehole (2) with average of $7 \%$. Whereas mixed layer of Illite- Smectite appeared only at 30 meter depth of $19 \%$ and $17 \%$ in borehole 1 and 2 respectively.

Table 3. Clay minerals distribution in borehole (1)

\begin{tabular}{lcccccccccccccc}
\hline $\begin{array}{l}\text { Clay } \\
\text { minerals }\end{array}$ & $3 \mathrm{~m}$ & $9 \mathrm{~m}$ & $13 \mathrm{~m}$ & $17 \mathrm{~m}$ & $23 \mathrm{~m}$ & $26 \mathrm{~m}$ & $27 \mathrm{~m}$ & $28 \mathrm{~m}$ & $30 \mathrm{~m}$ & $32 \mathrm{~m}$ & $35 \mathrm{~m}$ & $40 \mathrm{~m}$ & Average & Rang \\
\hline Cl- M\% & 18 & - & 20 & 38 & 54 & 37 & 41 & 13 & - & - & - & - & 19 & $13-54$ \\
$\mathrm{M} \%$ & 17 & - & 11 & - & - & 7 & - & - & 14 & 15 & 25 & 30 & 10 & $7-30$ \\
Ch\% & - & 42 & 22 & - & - & - & - & 8 & - & - & - & - & 6 & $8-42$ \\
$\mathrm{I}-\mathrm{P} \%$ & - & - & - & - & - & 31 & - & - & - & - & - & - & 2 & - \\
$\mathrm{I} \%$ & 45 & 37 & 21 & 8 & 7 & 5 & - & 10 & 4 & 30 & 35 & 25 & 20 & $4-45$ \\
$\mathrm{P} \%$ & - & - & 10 & 32 & 23 & - & 44 & 55 & 26 & 25 & 12 & 10 & 21 & $10-55$ \\
K\% & 20 & 20 & 17 & 18 & 15 & 16 & 15 & 14 & 13 & 10 & 8 & 8 & 15 & $8-20$ \\
Ver. \% & & - & - & - & - & - & - & - & 19 & 20 & 20 & 27 & 7 & $19-27$ \\
I-S\% & - & - & - & - & - & - & - & 19 & & & & 1 & - \\
\hline
\end{tabular}

Cl-M : Chlorite- Montmorillonite, M: Montmorillonite, Ch: Chlorite, I-P: Illite- Palygoreskite, I: Illite P: Palygoreskite, K: Kaolinite, Ver: Vermiculite, I-S: Illite-Smectite

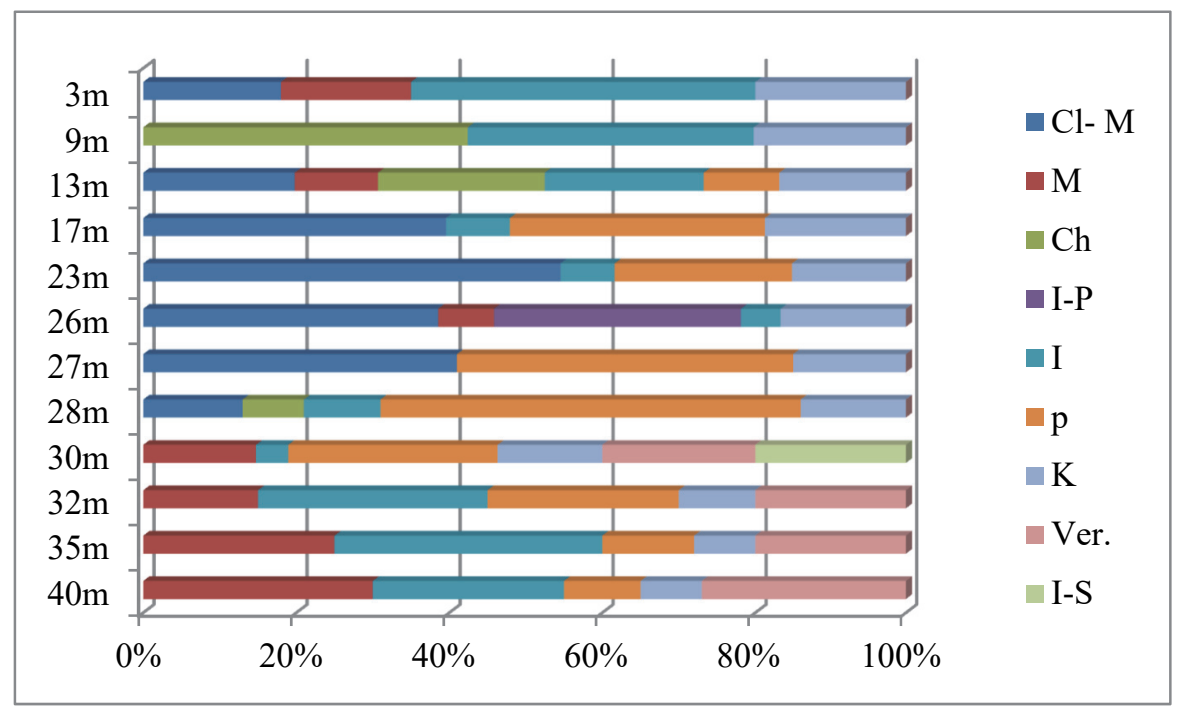

Figure 4. Clay mineral variations through depth in borehole (1) 
Table 4. Clay minerals distribution in borehole (2)

\begin{tabular}{lcccccccccccccc}
\hline $\begin{array}{l}\text { Clay } \\
\text { minerals }\end{array}$ & $3 \mathrm{~m}$ & $9 \mathrm{~m}$ & $13 \mathrm{~m}$ & $17 \mathrm{~m}$ & $23 \mathrm{~m}$ & $26 \mathrm{~m}$ & $27 \mathrm{~m}$ & $28 \mathrm{~m}$ & $30 \mathrm{~m}$ & $32 \mathrm{~m}$ & $35 \mathrm{~m}$ & $40 \mathrm{~m}$ & Average & Rang \\
\hline Cl- M\% & 15 & - & 18 & 35 & 51 & 33 & 32 & 17 & 4 & 3 & - & - & 18 & $13-54$ \\
$\mathrm{M} \%$ & 20 & 7 & 8 & - & - & 6 & 7 & - & 14 & 17 & 22 & 30 & 11 & $6-30$ \\
$\mathrm{Ch} \%$ & & - & 40 & 20 & 7 & - & - & 5 & 3 & - & - & - & 6 & $3-40$ \\
$\mathrm{I}-\mathrm{P} \%$ & - & - & - & - & - & 38 & - & - & - & - & - & - & 3 & - \\
$\mathrm{I} \%$ & 40 & 30 & 23 & 7 & 8 & 7 & - & 9 & 5 & 32 & 36 & 23 & 19 & $5-40$ \\
$\mathrm{P} \%$ & - & - & 11 & 31 & 25 & - & 46 & 57 & 27 & 20 & 14 & 12 & 21 & $11-57$ \\
$\mathrm{~K} \%$ & 25 & 22 & 20 & 18 & 15 & 14 & 13 & 12 & 11 & 9 & 8 & 7 & 15 & $7-25$ \\
Verm $\%$ & - & - & - & - & - & - & - & - & 18 & 19 & 19 & 27 & 7 & $18-27$ \\
$\mathrm{I}-\mathrm{S} \%$ & - & - & - & - & - & - & - & - & 17 & - & - & - & 1 & - \\
\hline
\end{tabular}

Cl-M : Chlorite- Montmorillonite, M: Montmorillonite, Ch: Chlorite, I-P: Illite- Palygoreskite, I: Illite P: Palygoreskite, K: Kaolinite, Ver: Vermiculite, I-S: Illite-Smectite

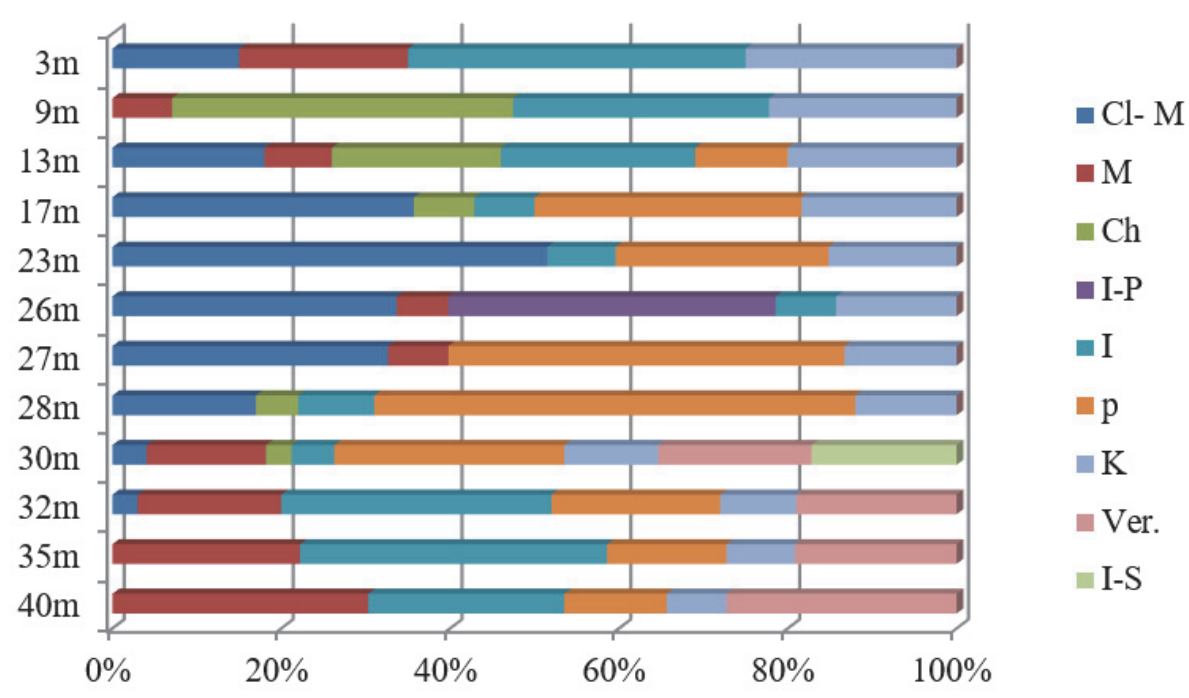

Figure 5. Clay mineral variations through depth in borehole (2)

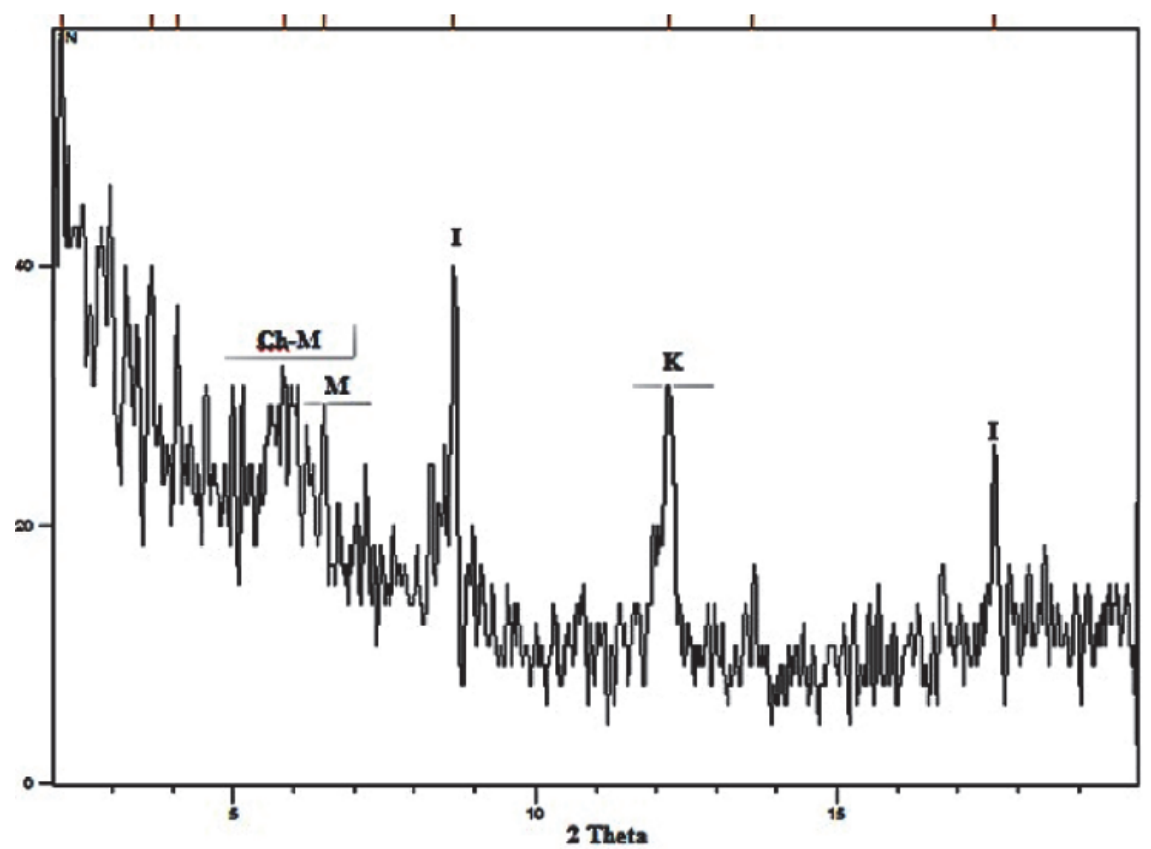

Figure 6. X- ray diffraction of sediments at 3 meter 


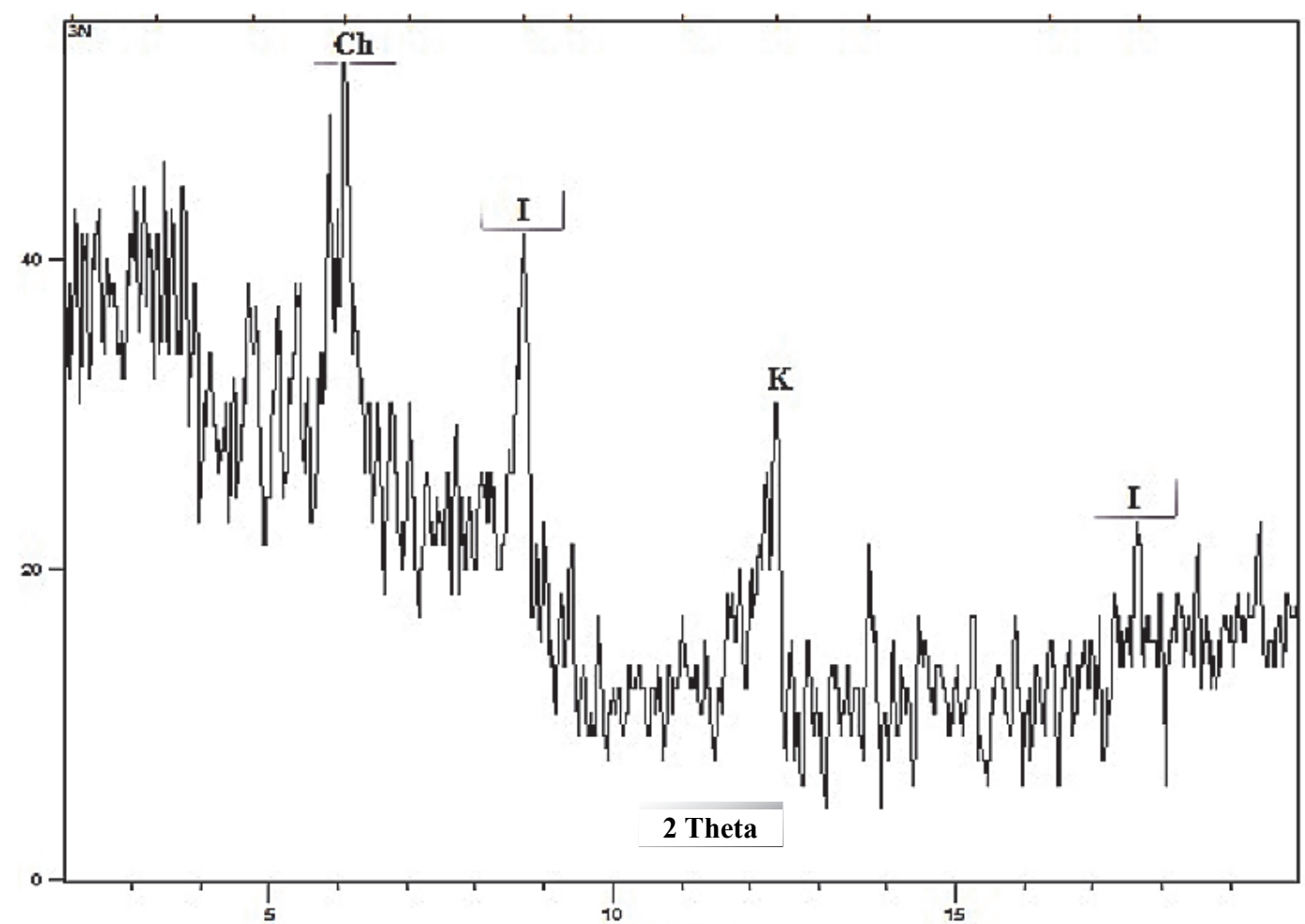

Figure 7. X-ray diffraction of sediments at 9 meter

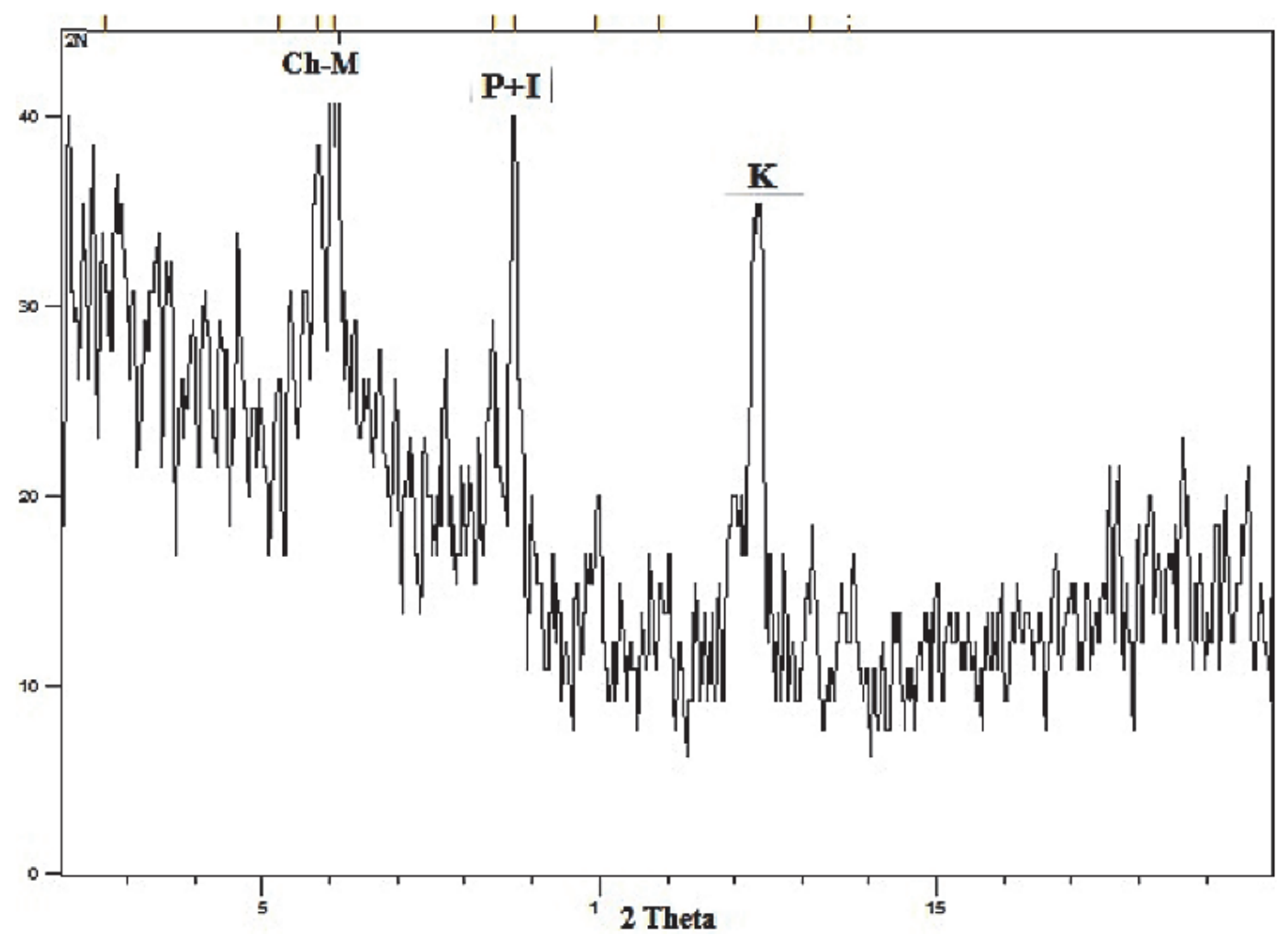

Figure 8. X- ray diffraction of sediments at 13 meter 


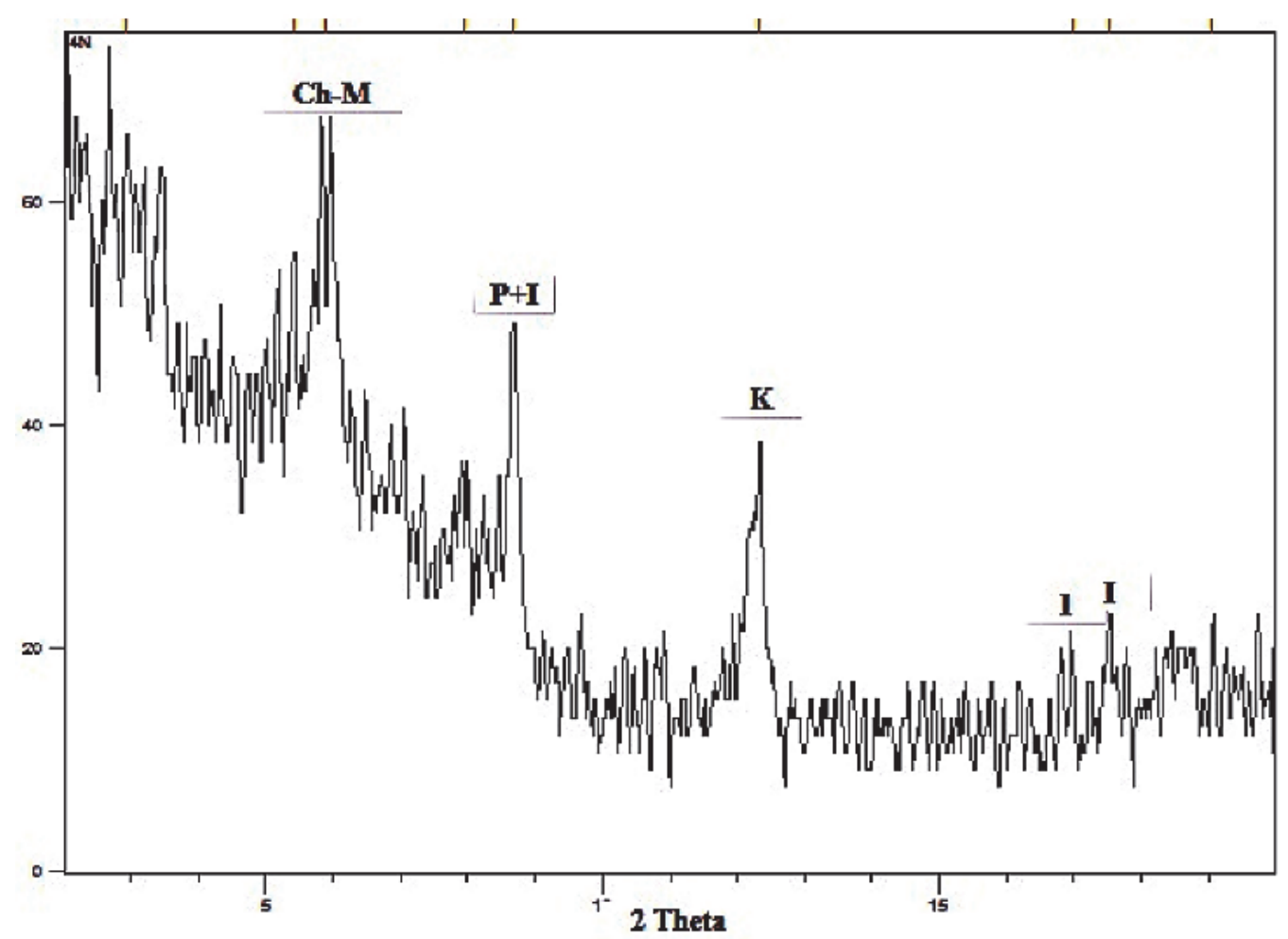

Figure 9. X- ray diffraction of sediments at 17 meter

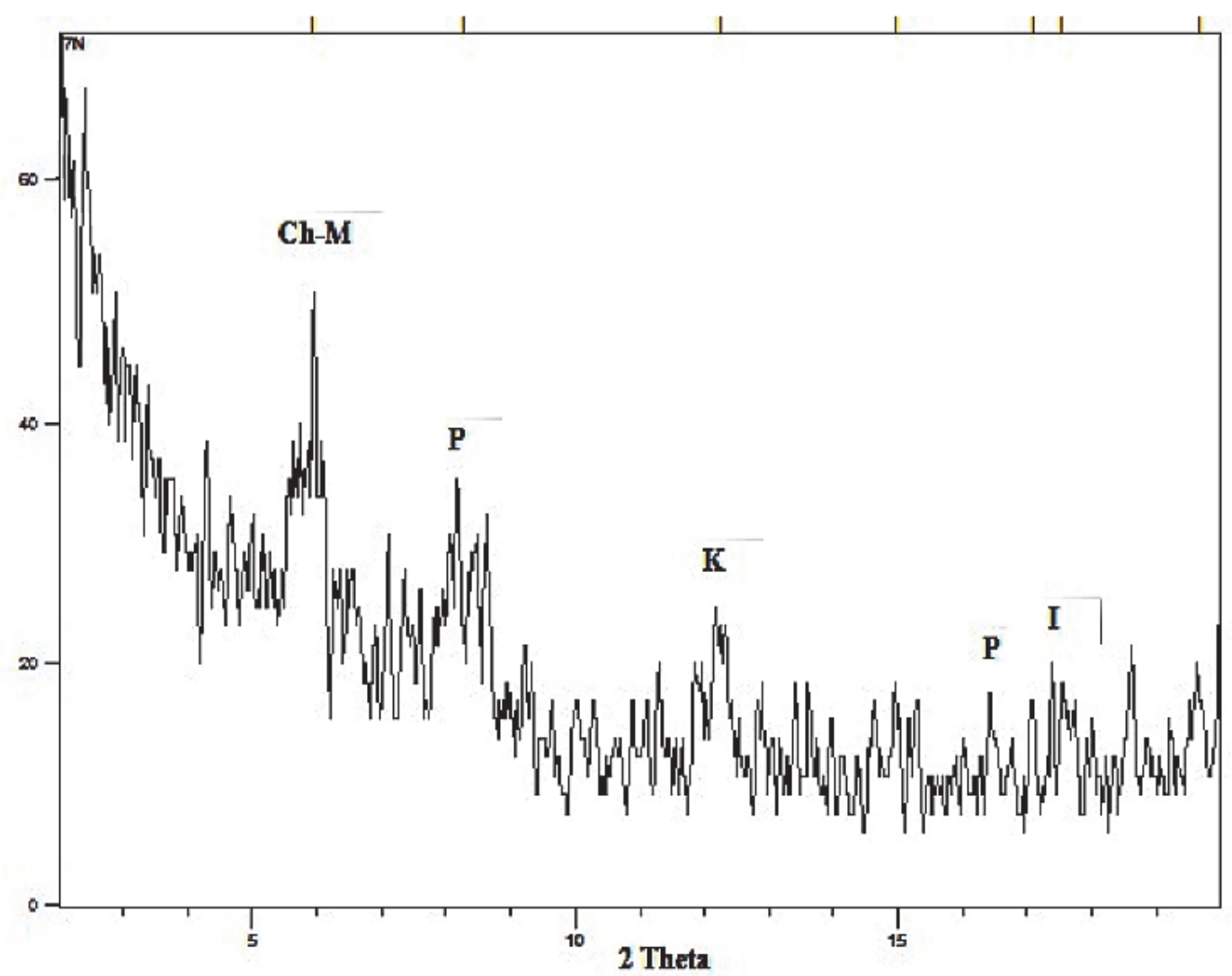

Figure 10. X- ray diffraction of sediments at 23 meter 


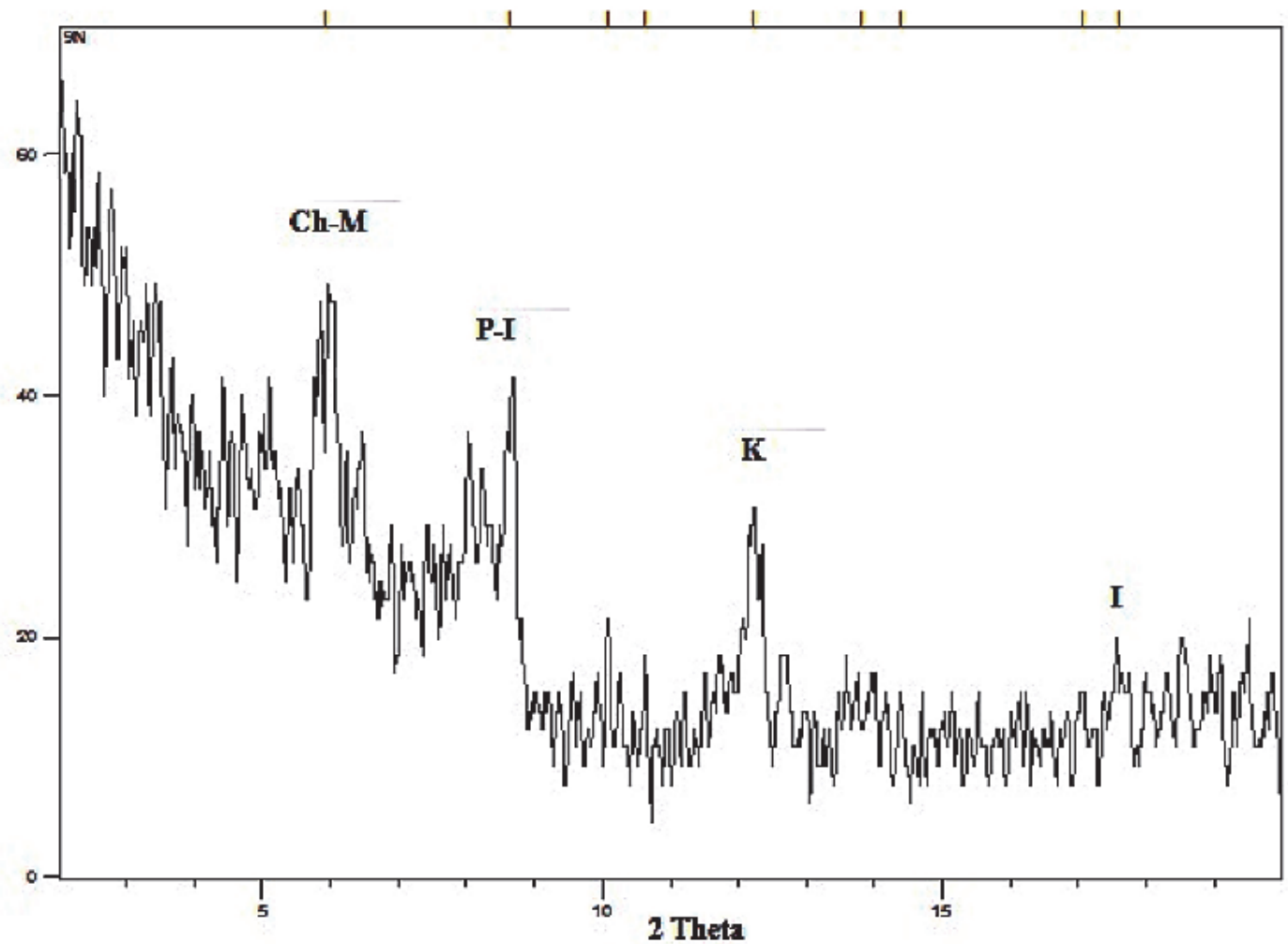

Figure 11. X- ray diffraction of sediments at 26 meter

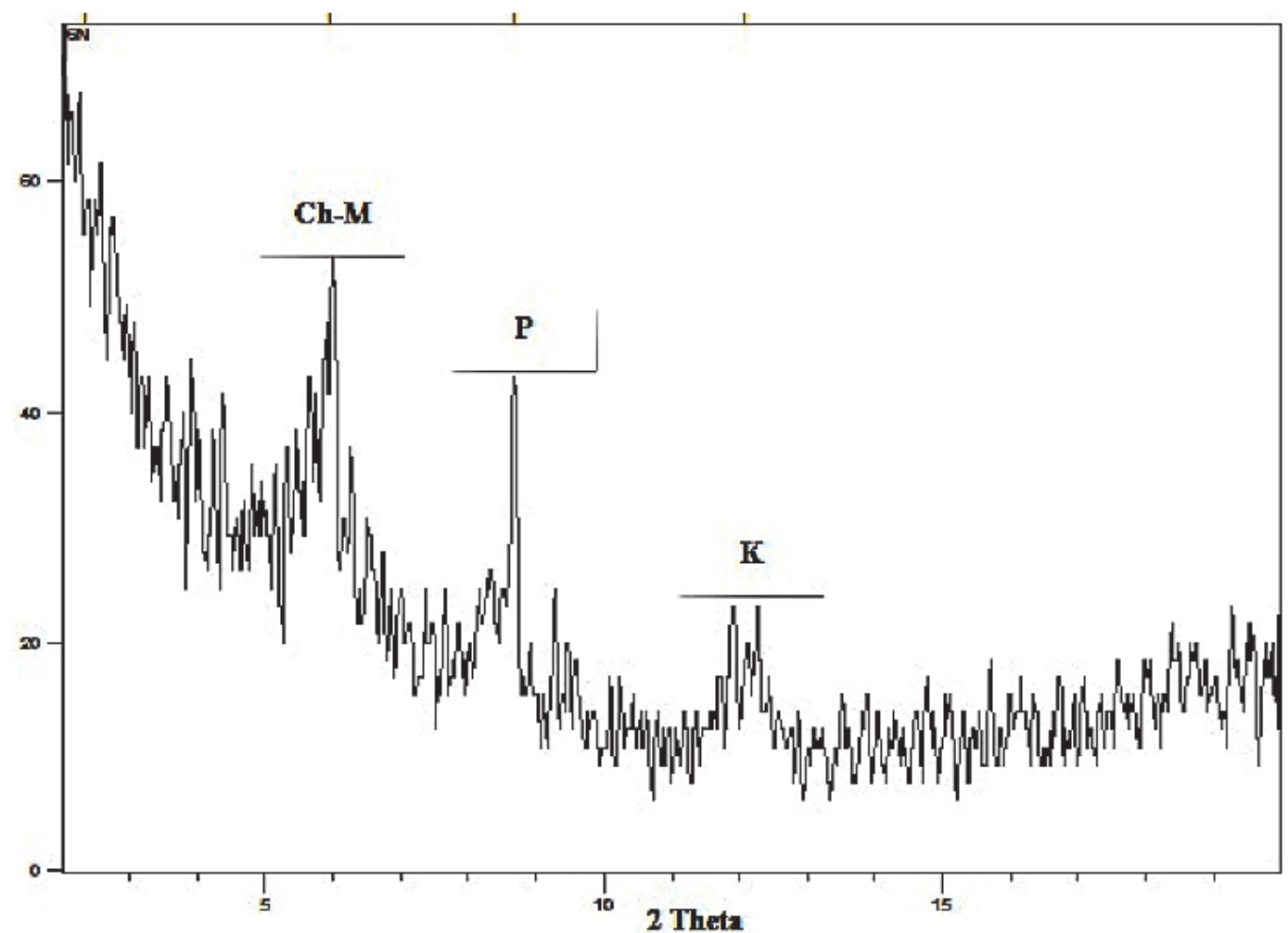

Figure 12. X- ray diffraction of sediments at 27 meter 


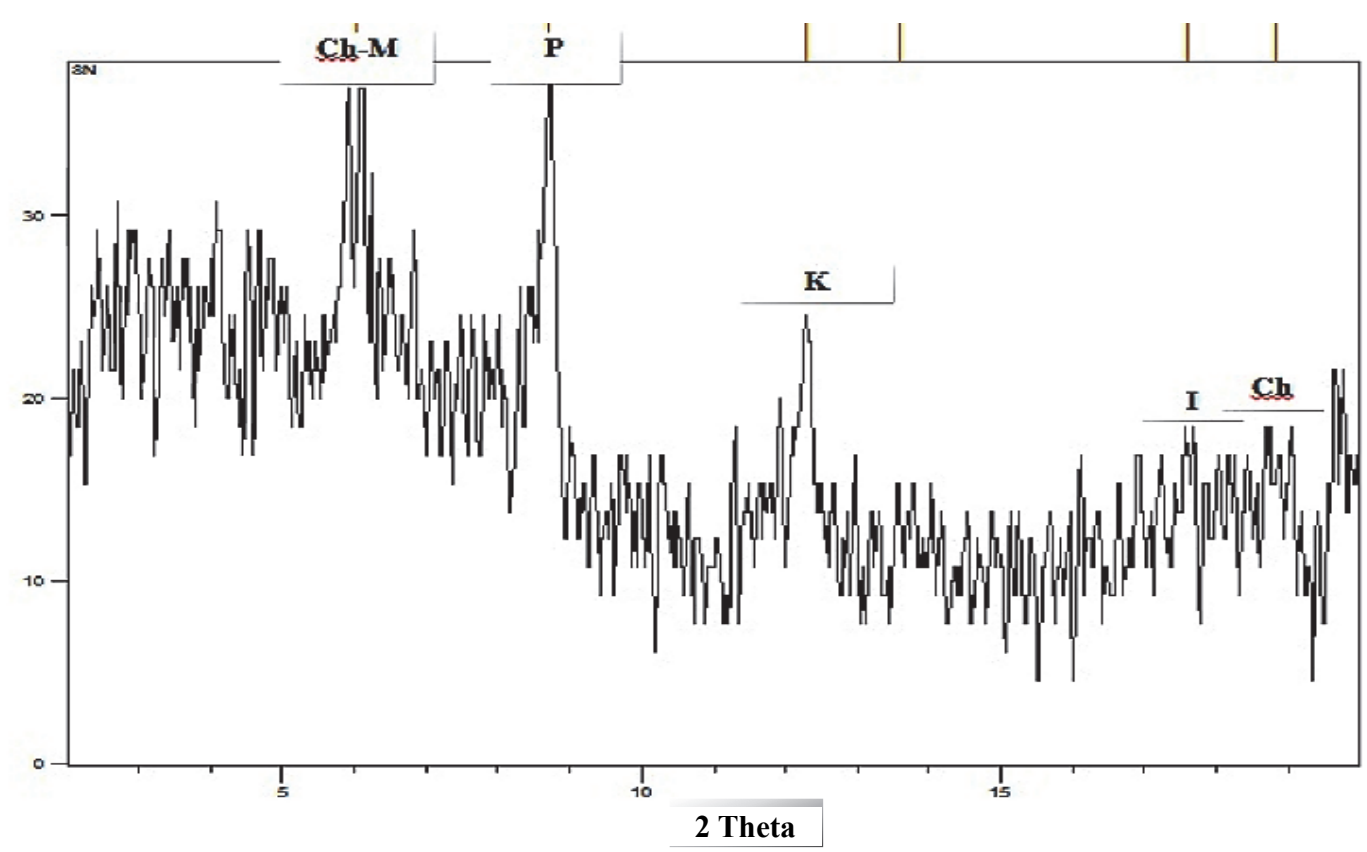

Figure 13. X- ray diffraction of sediments at 28 meter

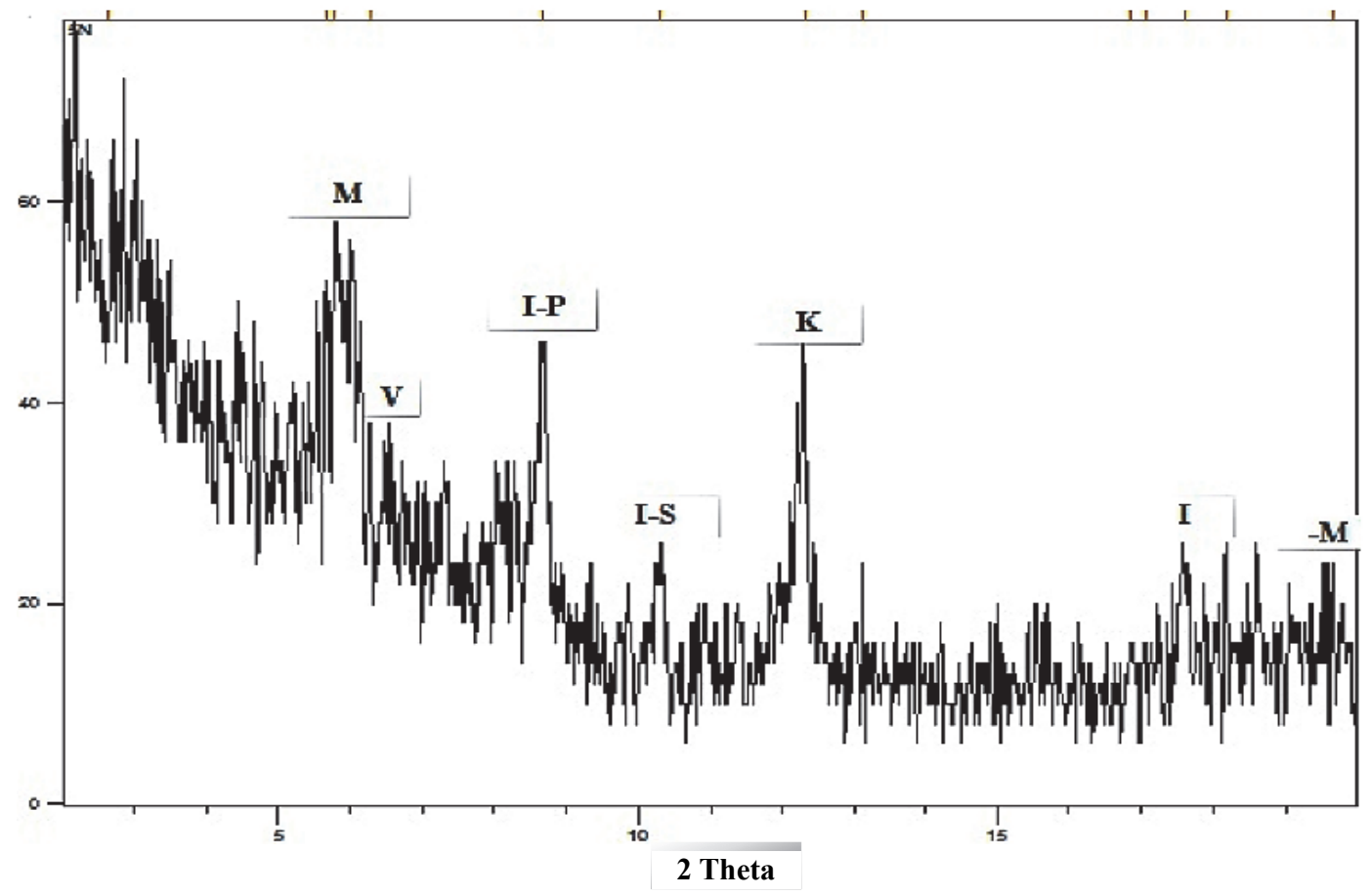

Figure 14. X- ray diffraction of sediments at 30 meter 


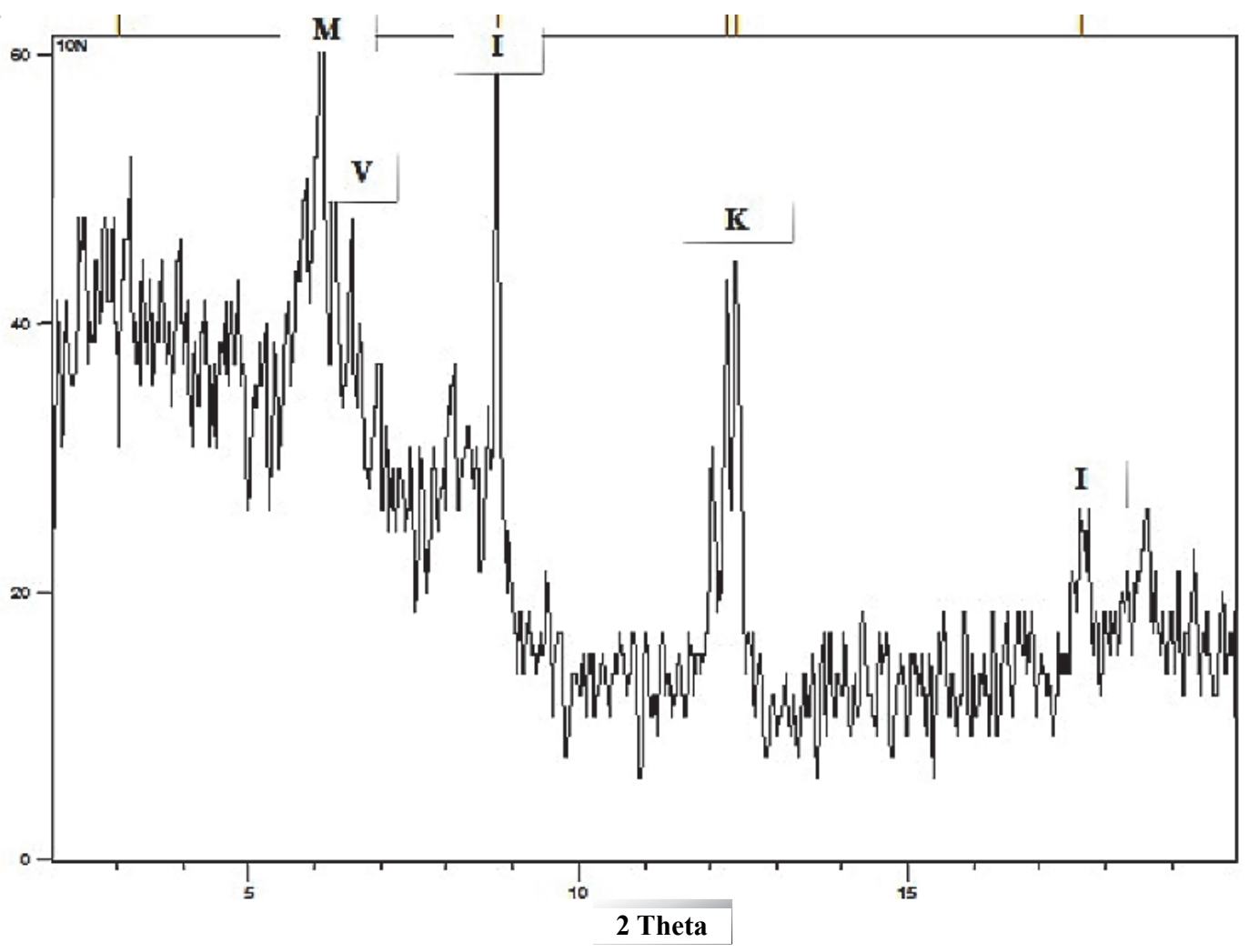

Figure 15. X- ray diffraction of sediments at 32 meter

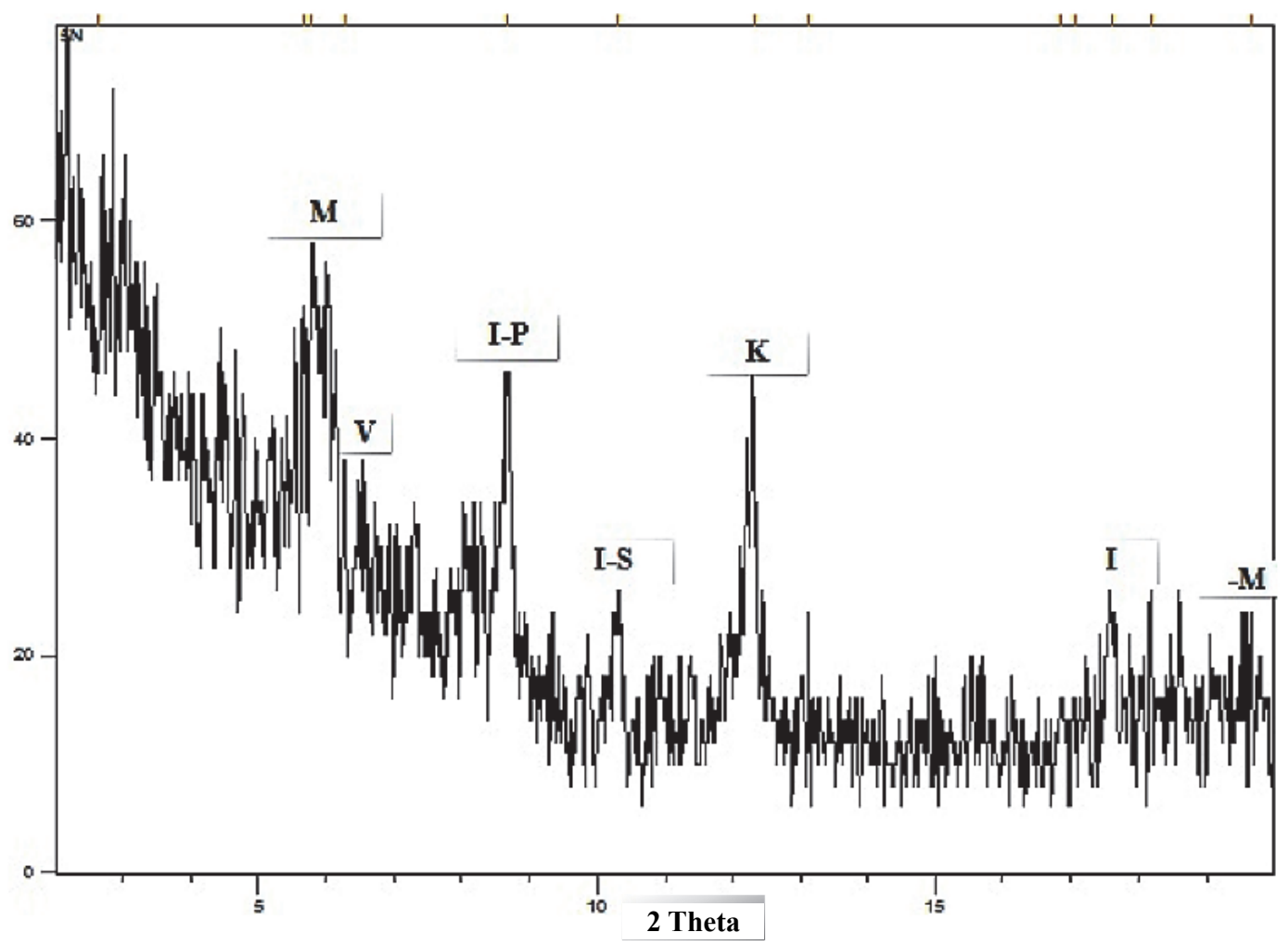

Figure 16. X- ray diffraction of sediments at 35 meter 


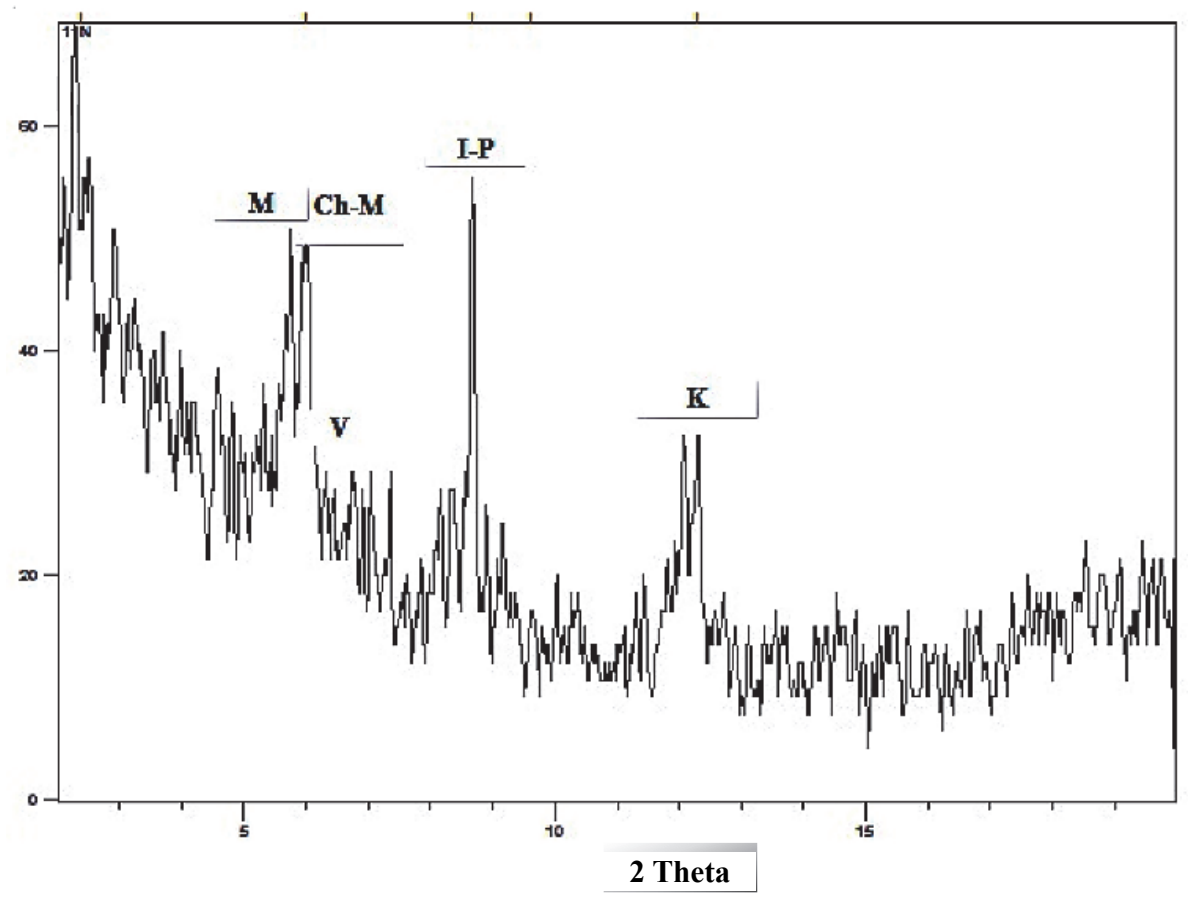

Figure 17. X- ray diffraction of sediments at 40 meter

\section{Discussion}

Depth distribution of clay minerals can be used to infer the sediment provenance and its variability through time (Pal et al., 2012). Present study is representing by study of clay minerals distribution and their variations in quaternary deposits that advertised by recent deposits and Hammar formation. Nine principal clay minerals were recognized in cutting sediments: Kaolinite, Illite, Palygoreskite, Illite-Palygorestike mixed layer, Chlorite, Smectite, Vermiculte, and mixed layers of Illite- Smectite.

The mineralogical composition of sediments shows significant variability in the different size fractions and depth distribution, for example, the content of chlorite and kaolinite increase in the fine grain size especially in the clayey silt, whereas the montmoriollinite, and vermiculite were increase in the coarse grains especially in the silty sand texture. Variations of clay minerals assemblage may be caused by a change of climate or sediment source. Soil ageing is characterized by a variation in clay mineral types that increase with age (Costantini and Damiani, 2004 and Pal et al., 2012). Kaolinite were decreased from $20 \%$ to $8 \%$ at borehole 1, and from $25 \%$ to $7 \%$ at borehole 2 in 3 and 40 meter depth respectively ( Tables 3 and 4, figures 4 and 5), this trend is probably indicative of a transition from non marine in quaternary recent sediment ( fresh or brackish water silt) to marine facies in quaternary Hammar formation ( marine shelly silt) during last transgression of quaternary (Tables 1 and 2) which supports the interpretation of detrital origin for kaolinite as previously mentioned by both of Gurel and Kadir (2010). The present results are the same as Hudson et al. (1957), Geukens (1966), Najar (1989) and AlJumaily (1994) results which emphasizes that the marine Hammar formation were found at depth of 17-18 meter in Basrah city. Palygoreskite mineral is increased from $44 \%$ to $55 \%$ at depth 27 and $28 \mathrm{~m}$ in borehole 1 respectively, and from $46-57 \%$ in 27 and 28 meter of borehole (2), after these percentages decreased directly in $30,32,35$, and $40 \mathrm{~m}$ to reach for $10 \%$ (Tables 3 and 4 ), which give data indication that early quaternary marine transgression happened in $30 \mathrm{~m}$, and center of quaternary marine transgression detected in 27 and 28 meters, while late marine transgression detected in $17 \mathrm{~m}$, and all of these represent by Hammar formation. A hopeful note was sounded by Al-Jaberi (2015) who concluded that most origin of palygoreskite mineral is autigenis because the inner structure of this mineral prevent it to transport for long distance, and the marine environments with high rate of temperature, evaporation, salinity, and alkalinity are suitable condition to form this mineral in-Situ. Soil ageing also caused to downward increase of montmorillonite from $17 \%$ in 3 meter to more than $30 \%$ in 40 meter of borehole (1) (Figure 4), whereas, it increased from $20 \%$ in 3 meter to $30 \%$ in 40 meter in borehole (2) (Figure 5), indicated that the climate became more arid (Jing Chen et al., 2014) during the early quaternary. Variations ratio of montmorillonite versus kaolinite can be indicated to climatic fluctuation. There are reverse relationship between montmorillonite and palygoreskite minerals (Tables 3 and 4), showing the same results of 
Mackanzie et al. (1981) and Al-Jaberi (2015), reported that palygoreskite mineral formed during dissolve montmorillonite mineral in alkaline environment with content of silica and magnesium. Illite- Smectite mixed layer can be detected at $30 \mathrm{~m}$ depth. Perry and Hower (1970) postulated that smectite transformation to mixed layer Illite-Smectite phase has been reported by several investigator to be a consequence of burial diagenses. Chen et al. (2014) visualized that Illite-Smectite featured indicates changes in both sediment source and paleoclimate. Content and crystallinity of illite, sensitive to climate change, records the strong fluctuations of the climate during quaternary as mentioned previously by Chen et al. (2014). Illite transformation for I-P mixed layers with ageing. Vermiculite have strong susceptibility to increase with age (Costantini and Damiani, 2004), for this reason it appear in a higher depth cutting at 30, 32, 35and 40 meters. Vermiculite increase through transformation of illite and chlorite into a series of intermediate HIV and mixed layer. Soil ageing causes a variations in the composition of clay mineral producing trends through the horizons, changes continue to occur in older horizons and are prominent for each of kaolinite, montmoillonite and vermiculte. Major oxides Variations at different depths clarified and depicted at table 5 and figure 18. Silica sediments content is present at lower percentages at 3 to 23 meters, thereafter it starting increase at 26 to 40 meters. $\mathrm{SiO}_{2}$ increase with increasing depth could be indicator of higher sand contents with depth increasing in both boreholes. $\mathrm{Al}_{2} \mathrm{O}_{3}$ decreased gradually upward coring as indication to decrease of Kaolitite mineral. Larsen and chilingar (1967) and Al-Jaberi (2005) postulated that kaolinite mineral is a high alumina clay with alumina percent between $20 \%$ to $40 \%$ from the whole oxides component. There are reverse relationship between both of Alumina and Silica, this result may lead to increase sand sediments content with decrease of clay minerals especially kaolinite minerals. $\mathrm{CaO}$ and $\mathrm{MgO}$ increasing with increase of palygoreskite mineral in depths 27 and 28 meters. Most of the following information is based on the work of Aqrawi (1993) and Velde (1993) gave date indications to magnesium and calcium ions in the saline alkaline environment are the suitable environment to form palygoreskite in situ. While $\mathrm{Na}_{2} \mathrm{O}$ increase with downward coring as indicator to high montmorillonite contents with increase depth. A hopeful was sounded by Weaver and Pollard (1976) that sodium oxides content in montmorillonite was more than other clay minerals. On the other hand, can be used Potassium Oxides $\left(\mathrm{K}_{2} \mathrm{O}\right)$ as index for Illite minerals present, and observed abundance of $\mathrm{K}_{2} \mathrm{O}$ with higher percentages at depths $3,9,13,32$, 35, and 40 meters, giving a good evidence of higher Illite at these depths. Selley (1994) and Weaver and Pollard (1967) mentioned that potassium oxides reached from $7.2 \%$ to $8 \%$ in Illite minerals. Iron oxides present in higher percent in chlorite mineral as showed by Correns (1973) reach to more than $8 \%$. Iron oxides decreased with depths, this result can be used to interpreted to decrease of Chlorite mineral at these depths.

Table 5. ICP analysis of cutting sediments

\begin{tabular}{lrrrrrrrrrrrr}
\hline Major oxides & $3 \mathrm{~m}$ & $9 \mathrm{~m}$ & $13 \mathrm{~m}$ & $17 \mathrm{~m}$ & $23 \mathrm{~m}$ & $26 \mathrm{~m}$ & $27 \mathrm{~m}$ & $28 \mathrm{~m}$ & $30 \mathrm{~m}$ & $32 \mathrm{~m}$ & $35 \mathrm{~m}$ & $40 \mathrm{~m}$ \\
\hline $\mathrm{SiO}_{2} \%$ & 30 & 31 & 32 & 31 & 30 & 49.6 & 49.9 & 50 & 51 & 51.5 & 56 & 57 \\
$\mathrm{Al}_{2} \mathrm{O}_{3} \%$ & 11 & 13 & 10.4 & 10.2 & 10.5 & 9.96 & 8.87 & 7.2 & 7.1 & 6.8 & 6.5 & 6.4 \\
$\mathrm{Na}_{2} \mathrm{O} \%$ & 1.8 & 1.6 & 1.5 & 1.55 & 1.6 & 1.5 & 1.4 & 1.43 & 1.65 & 1.66 & 1.72 & 1.8 \\
$\mathrm{Fe}_{2} \mathrm{O}_{3} \%$ & 3 & 7 & 6.7 & 6.8 & 7 & 5 & 4.2 & 4.4 & 4 & 3.5 & 2.5 & 2.6 \\
$\mathrm{CaO} \%$ & 19 & 18 & 19 & 20 & 21 & 22 & 23 & 23.7 & 23.9 & 22.7 & 21 & 20.8 \\
$\mathrm{~K}_{2} \mathrm{O} \%$ & 1.54 & 1.32 & 1.28 & 1.21 & 1.2 & 1.12 & 1.1 & 0.98 & 0.88 & 1.23 & 1.35 & 1.33 \\
$\mathrm{MgO} \%$ & 5.54 & 5.23 & 5.7 & 7.3 & 6.9 & 7.1 & 8.1 & 8.4 & 7.4 & 7.2 & 6.3 & 5.4 \\
$\mathrm{L.o.I} \%$ & 23 & 20 & - & - & - & 3 & 2 & 3 & 3 & 3 & 4 & 3 \\
\hline
\end{tabular}

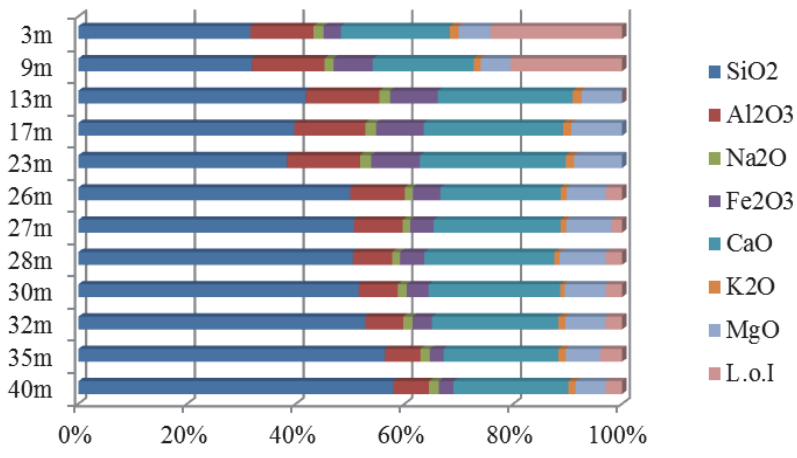

Figure 18. Major oxides variations through depth 


\section{Conclusion}

1) Clayeysilt texture is a dominant texture from surface sediments tell depth at $23.5 \mathrm{~m}$ in borehole 1 and $21.5 \mathrm{~m}$ in borehole 2, while siltysand is a dominant texture after that depths.

2) Chlorite and kaolinite minerals were increase in the clayeysilt texture, whereas montmoriolllinite and vermiculite minerals were increase in the siltysand texture.

3) Kaolinite and palygoreskite indicated to transgression and or / regression in Hammar formation.

4) Montmotillionite, Vemmiculite, Mixed layers of Illite-Palygoreskite and Illite- Smectite minerals are refer to soil aging with depth.

5) $\mathrm{SiO}_{2}, \mathrm{Al}_{2} \mathrm{O}_{3}, \mathrm{CaO}, \mathrm{MgO}, \mathrm{K}_{2} \mathrm{O}$ and $\mathrm{Fe}_{2} \mathrm{O}_{3}$ are used to identify of clay minerals present in sediments of studied area.

\section{References}

Al-Jaberi, M. H. (2010). Sedimentological and environmental aspects of sub-surface Basrah sediments- South Iraq. Mesopt. J. Mar. Sci., 25(2), 67-78.

Al-Jaberi, M. H. (2015). Study of the clastics and shells in selected areas at NW of Arabian gulf- south Iraq, Scholars Press publish house, Germany, 248p.

Al-Jumaily, W. (1994). Quaternary ostracodes in southern Iraq. Unpublished master thesis, Baghdad University, $117 \mathrm{P}$.

Aqrawi, A. A. M. (1993). Palygorskite in the recent fluvoi- Lacustine and deltaic sediments of southern Mesopotamia. Research of Clay Minerals, 28, 153-159.

Bini, C., \& Mondini, C. (1992). Clay mineralogy of paleosols at archaeological sites in mediterranean environment, Italy- Miner. Petrogr. Acta, 35(A), 245-252.

Brindley, G. W., \& Brown, G. (1980). Crystal Structures of Clay Minerals and their X-Ray Identification. Mineralogical Society of Great Britain and Ireland. https://doi.org/10.1180/mono-5, 280P

Bronger, A., Bruhn-Lobin, N., \& Heinkele, T. (1994). Micromorphology of paleosols - genetic and paleoenvironmental deductions: Case studies from central China, south India, NW Morocco and the Great Plains of the USA. Journal of Development in Soil Science, 22, 187-206.

Budy, T. (1980). The Regional of Iraq stratigraphy and paleography state organization for minerals, Dar Al- Kutb Publishing house, Mosul, Iraq, 443P.

Carroll, D. (1970). Clay minerals: A Guid to Their X-ray Identification Geo, Soc. America, 80P.

Chen, J., Wang, Z, Wei, T., Zhao, B., \& Chen, Z. (2014). Clay minerals in the Pliocene- Quaternary sediments of the southern Yangtze coast, China: Sediment sources and paleoclimate implications. Jour. of paleogeography, 3(3), 297-308. https://doi.org/10.3724/SP.J.1261.2014.00057

Correns, C. W. (1978). Die Sediments Des aquatorialian Atlantisschan Ozean. Wiss. Erogebn. dt. Atlant. Exped. Meteor, 298P.

Costantini, E. A. C., \& Damiani, D. (2004). Clay minerals and the development of Quaternary soils in central Italy. Revista Mexicana de Ciencias Geológicas, 21, 144-159.

Costantini, E. A., Lulli, D., Bidini, R., Napoli, \& Castellani, F. (1992). Karts landformes and soils of the Poggio del Comune relief (Central Italy), 83-130. In Proceeding of the karst-symposium - Blaubeuren. 2nd Inter. Conf. Geomorphology, 1989, heft 109.

Geukens, F. S. (1966). Geology of the Arabian Peninsula, Yemen. Professional Paper. Report. U.S. Geol. Survey, Washington D.C., Series No. 560, B1-B23.

Gurel, A., \& Kadir, S. (2010). Palaeoenvironmental approach to the geology, mineralogy and geochemistry of an Early Miocene alluvial-fan to cyclic shallow-lacustrine depositional system in the Aktoprak Basin (Central Anatolia), Turkey. Jour. of Clay Minerals, 45(1), 23-45. https://doi.org/10.1180/claymin.2010.045.1.51

Hudson, R. G., Eames, F., \& Wilking, G. L. (1957). The fauna of some recent marine deposits near Basrah, Iraq. Geol. Mag., 94, 393-401.

Iacoviello, F., \& Martini, I. (2012). Provenance and geological significance of red mud and other clastic sediments of the Mugnano Cave (Montagnola Senese, Italy). International Journal of Speleology, 41(2), 317-328. Tampa, F. L. (USA). ISSN 0392-6672. http://dx.doi/org/10.5038/1827-806X.41.2.17

Keller, W. D. (1970). Environmental Spects of Clay minerals. Jour. Sed. Pet., 40, 788-814. 
Larsen, G., \& Chilingar, G. V. (1967). Diagenesis in sediments. Uni. Of southern California, Los Angeles, Calif, (USA). 551P.

Mackanzie, R. C., Wilson, M., \& Mash, A. S. (1981). Origin of palygorskite in some soils of Arbian Peninsula. In singer, \& Galan, E. (Eds.), palygorskite - sepiolite occurrences Genesis and uses Development in sedimentology, 37, 177-186.

Millot, G. (1970). Geology of clay. Springer Verlag, New York, Heidelbry, Ber line, 429P.

Najar, I. M. (1989). Paleomagnetic study to determine the age of recent sediments south Iraq. Unpublished Master thesis, Baghdad University, 116P.

Pal, D. K., Bhattccharyya, T., Sinha, R., Srivastava, P., Dasgupta, A., Chandran, P., Ray, S., \& Nimje, A. (2012). Clay minerals record from late quaternary drill cores of the Ganga plain and their implications for provenance and climate change in the Himalayan foreland. Jour. of Paleogeographic, paleoclimatology, Paleoecology, 356-357, 27-37. https:/doi.org/10.1016/j.palaeo.2011.05.009

Perry, E., \& Hower, J. (1970). Burial diagenesis in Gulf Coast pelitic sediments. Clays \& Clay Minerals, 18, 165-177.

Picard, M. D. (1971). Classification of fine-grained sedimentary rocks: J. Sediment. Petrol, 41, Reprinted by permission of Society for Sedimentary Geology, Tulsa, OK.

Reynolds, R. C. (1980). Interstratified clay minerals. In Crystal Structures of Clay Minerals and Their X-ray Identification, G. W. Brindley and G. Brown, eds., Mineralogical Society, London, 249-304.

Selley, R. C. (1976). An Introduction to sedimentology academic press, London, 406P.

Selley, R.C. (1994). Applied sedimentology, Academic Press, London, 446P.

Tucker, M. E. (1985). Sedimentary petrology, an introduction (4th ed.). Black well scientific Publick., 252P.

Vanderaveroet, P., Averbuch, O., deconenck, J., \& Chamley, H. (1999). A record of clacial / interglacial alternations in Pleistocene sediments of New Jersey expressed by clay mineral, grain size and magnetic susceptibility data. Marine Geology, 159, 79-92.

Velde, B. (1992). Introduction to clay minerals chemistry, origins, uses and environmental significance, National center for scientific research, France, 196P.

Weaver, C. E., \& Pollared, D. E. (1975). The chemistry of clay minerals. Development in sedimentolgy, part 15, Elsevier scientific publ. Co., New york, 213P.

\section{Copyrights}

Copyright for this article is retained by the author(s), with first publication rights granted to the journal.

This is an open-access article distributed under the terms and conditions of the Creative Commons Attribution license (http://creativecommons.org/licenses/by/4.0/). 